\title{
The heritage of the League of Nations' minority protection system
}

\author{
HARALD CHRISTIAN SCHEU*
}

Charles University, Faculty of Law, Czech Republic

\section{ORIGINAL RESEARCH PAPER}

Received: February 8, 2019 • Accepted: October 24, 2019

Published online: January 13, 2022

(C) 2021 Akadémiai Kiadó, Budapest

\section{ABSTRACT}

This paper discusses the system of minority protection of the League of Nations. Minority protection occupied a prominent place on the League's agenda, which developed a significant expertise in the field. The League's system of minority protection is often regarded as an experiment. With regard to both material and procedural aspects this assessment is certainly correct. In particular, minority protection based upon legally binding treaties and declarations gave rise to the question of how individual and group rights should be treated within the frame of an international political organization. The paper further examines whether at least some of the elements of the League's minority protection system still persist in the context of contemporary international human rights law.

\section{KEYWORDS}

League of Nations, international law, human rights, minority protection, international organisations

\section{INTRODUCTION}

When in August 1946 the Assembly of the League of Nations decided to terminate the existence of the organization and to transfer its services and properties to the newly founded United Nations Organization, the international community almost failed to notice this fact. According

\footnotetext{
*Corresponding author. E-mail: scheu@prf.cuni.cz
} 
to Leland M. Goodrich, who analysed the transition from the League of Nations to the United Nations, the founders of the new organization hesitated to draw attention to the essential continuity of the old League and the new United Nations for fear of arousing latent hostilities or creating doubts which might seriously jeopardize the birth and success of the new organization. ${ }^{1}$ Thus, a promising experiment ended in embarrassment and silence. ${ }^{2}$

This seems to be a rather undeserved end to the first international organization intended to secure world peace and promote a valuable forum for international cooperation after the collapse of the old European order. Much idealism had been invested in creating a new mechanism of international law that at least partly outlawed war as a means of international politics and established concrete tools to render the use of military force between states more difficult. The fact that the League of Nations and its various instruments were not able to prevent the outbreak of World War II has significantly contributed to the failure thesis. ${ }^{3}$

On the other hand, we must not forget that besides collective security ${ }^{4}$ the League of Nations was dealing with a broad number of legal issues which enriched the system of international law and laid the foundation for the important achievements of the UN era and even contemporary international law. Despite some evident shortcomings the League's mandate system introduced the idea that the mandatory powers entrusted by the international community are internationally accountable for the population of former colonial territories. ${ }^{5}$ Also, the lessons learned by the League with regard to the preparation of international conventions have inspired similar codification attempts ${ }^{6}$ governed by the competent UN institution. So, in various fields of international law we may identify elements of continuity between the League of Nations and the UN system after 1945 .

In this paper we will focus on the field of national minority protection, which occupied a very prominent place on the League's agenda. Without doubt, the organization developed a significant expertise in this field of law. Various authors have called the League's system of minority protection an experiment. ${ }^{7}$ With regard to both material and procedural aspects this assessment is certainly correct. In particular, minority protection based upon legally binding treaties and declarations gave rise to the question of how individual and group rights should be treated within the frame of a political international organization.

\footnotetext{
${ }^{1}$ Goodrich (1947) 3-21.

${ }^{2}$ According to Susan Pedersen, the League of Nations was a 'favored subject of academic research' in the period after World War I. However, after the outbreak of World War II, and after 1945, academic interest in the subject diminished dramatically and 'for thirty years, the archives of the League's own Geneva Secretariat were very little disturbed'. See Pedersen (2007) 1091-1117.

${ }^{3}$ Charles G. Fenwick had already stated in 1936 that in the light of the success of the Italian campaign in Ethiopia, despite public condemnation of Italy by the League of Nations as an aggressor and despite economic sanctions applied by the League, a significant part of public opinion in the United States started to consider the League a 'failure.' According to Fenwick, however, there was only a failure of the plan of collective security embodied in Articles 10, 11 and 16 of the Covenant, as the other functions of the League remained substantially unaffected by the failure of collective security. See Fenwick (1936) 506-509.

${ }^{4}$ For a more balanced view on the failures and successes of the League's collective security system, see Tosi (2017) 148-57.

${ }^{5}$ For more details on the League's mandate system, see Pedersen (2007) 1104-1107.

${ }^{6}$ For an evaluation of the League's codification attempts, see Finch (1947) 611-16.

${ }^{7}$ See, for example, Weisbrod (1992) 359-406; Hilpold (2013) 87-124.
} 
We will analyse whether at least some of the elements of the League's minority protection system still persist in the context of contemporary international human rights law.

\section{THE MAIN ELEMENTS OF NATIONAL MINORITY PROTECTION UNDER THE LEAGUE OF NATIONS}

The League of Nations system of national minority protection was mainly built on bilateral treaties between the major victorious states of the First World War, the so-called Principal Allied and Associated Powers, ${ }^{8}$ on the one hand, and particular nation states on the other. Following the example of a minority treaty with Poland that was signed on June 29, 1919, largely identical minority treaties with Yugoslavia (September 10, 1919), Czechoslovakia (September 10, 1919), Romania (December 9, 1919) and Greece (August 10, 1920) were adopted. Similar commitments were included in unilateral declarations on the protection of national minorities which were filed by Albania (in October 1921), Estonia (in September 1923), Finland (in June 1921), Latvia (in June 1923), Lithuania (in May 1922), and Iraq as the only example of a non-European country (in 1932). In addition, provisions on the protection of national minorities were incorporated into several peace treaties (with Austria, Bulgaria, Hungary and Turkey) and specific status agreements (on Upper Silesia and the Memel Territory).

As far as the material standard of protection of national minorities is concerned, the relevant documents share very similar arrangements. ${ }^{9}$ The prohibition of discrimination occupies a very prominent place. For example, Article 2 of the model minority treaty with Poland provides equality for all inhabitants of Poland in areas such as the right to life, personal liberty and free exercise of any creed, religion or belief. According to Article 7 of the Polish minority treaty, all Polish nationals shall be equal before the law and shall enjoy the same civil and political rights without distinction as to race, language or religion.

Acquisition of citizenship by members of national minorities was another important issue. Article 3 of the model minority treaty with Poland states that Polish citizenship was ipso facto acquired by all persons who at the date of the coming into force of the present Treaty resided in the territory of the state, irrespective of their ethnic origin. Those who exercised the right to opt for any other nationality, were obliged to transfer within the succeeding twelve months their place of residence to the State for which they had opted.

Minority protection included rights relating to the use of the minority language, particularly in the private sphere, but partly also in court and within the system of education. According to Article 9 of the model treaty with Poland, the State had to provide adequate facilities for ensuring that in the primary schools the instruction was given to minority children through the medium of their own language. The concrete level of public support for minority language education depended on the proportion of members of national minorities in the total population of cities and districts. Article 9 of the Treaty between the Principal Allied and Associated Powers and Czechoslovakia (the so-called Little Treaty of Saint-Germain) refers to towns and districts

\footnotetext{
${ }^{8}$ Since the United States did not ratify the minority treaties, they did not become a treaty party.

${ }^{9}$ For more details, see Hilpold (2006) 156-89.
} 
'where there is a considerable proportion of the Czecho-Slovak nationals belonging to racial, religious or linguistic minorities'.

Only some minority treaties contained provisions on territorial autonomy, for example in favor of the Ruthene territory ${ }^{10}$ in the Czechoslovak Minority Treaty, ${ }^{11}$ or in favor of Transylvania in the Minority Treaty with Romania. The minority treaties with Poland, Greece and Romania included arrangements concerning specific rights of the Jewish minority. In the treaties with Greece and Yugoslavia we can find provisions on the status of Muslims. Provisions regarding Muslim family law were also incorporated into Article 2 of the Albanian Declaration of 1921.

As for the practical realization of these material rights, minority treaties refer to the League of Nations. Under Article 12 of the model treaty with Poland, the commitments made in favor of national minorities were placed under the guarantee of the League of Nations. This guarantee included three specific mechanisms. ${ }^{12}$ First, each member of the Council of the League of Nations had the right to bring to the Council's attention any infraction, or any danger of infraction, of any of treaty provisions. Secondly, the Council was entitled to take such action and give such direction as it deemed proper and effective in the circumstances. Third, the Minority Treaties refer to Article 14 of the Covenant on the League of Nations, according to which all disputes of an international character could be decided by the Permanent Court of International Justice. ${ }^{13}$ The minority treaties, therefore, concurrently stated that disputes over legal or factual issues related to the minority treaties were to be considered disputes of an international character. Any member of the Council of the League of Nations could refer such a case to the Court.

Although the minority treaties do not include a more precise regulation of the different procedures, it can be stated that minority treaties were based on an unprecedented interference with state sovereignty. ${ }^{14}$ While political interventions of kin-states for the benefit of their kinminorities abroad had been repeatedly recorded in the past, a system of national minority protection including international procedures was a crucial innovation. ${ }^{15}$

On the other hand, the control mechanism was characterized by a number of obvious weaknesses, which were mainly due to the fact that the operation of the system depended on the willingness of individual states to initiate international disputes over the interests of national minorities the members of which did not live on their territories and mostly did not have their citizenship rights. Right up to the present day, practice has shown that, under normal circumstances, States do not file international complaints or actions against other States because of alleged human rights or minority rights violations. As a rule, they do not want to disrupt

\footnotetext{
${ }^{10}$ On the quest for Carpatho-Rusyn autonomy, see Magocsi (2015) 577-94.

${ }^{11}$ Under Article 10 of the Little Treaty of Saint-Germain, Czechoslovakia undertook to constitute the Ruthene territory south of the Carpathians within frontiers delimited by the Principal Allied and Associated Powers as an autonomous unit within the Czecho-Slovak State, and to accord to it the fullest degree of self-government compatible with the unity of the Czecho-Slovak State. Articles 11 and 12 of the Treaty refer to the establishment of a special Diet as the Ruthene Legislative Assembly and the office of a Governor responsible to the Ruthene Diet.

${ }^{12}$ For a profound contemporary analysis of the League's role as guarantor of the rights of minorities, see Stone (1932).

${ }^{13}$ On the role of the Permanent Court of International Justice, see Brölmann (2013) 123-43.

${ }^{14}$ On the innovative character of the League's minority régime, see Cowan (2003) 271-91.

${ }^{15}$ Gardiner Jones (1949) 609.
} 
standard diplomatic relations. ${ }^{16}$ This is also true for the approach adopted by kin-states. When they intended to support their kin-minorities they opted for milder measures, rather than submitting to the Council or appealing to the Permanent Court of International Justice. Under the system of the League of Nations, between 1929 and 1932, the tool of a state complaint was used only three times, always by Germany in support of German minorities abroad. ${ }^{17}$

The reluctance of members of the Council to take action against states violating international obligations in the field of minority protection was not the only weakness of the system. Decision-making in the Council was also quite complicated. According to Article 5 of the Covenant on the League of Nations, a decision of the Council had to be taken with the consent of all members. In the politically sensitive area of national minority protection, unanimity was barely achievable. Under the minority treaties members of national minorities and national minorities themselves as directly affected entities were not entitled to take any formal procedural steps before the League of Nations and the Permanent Court of International Justice. ${ }^{18}$

\section{THE MINORITY PETITION PROCEDURE OF THE COUNCIL}

In view of the above-mentioned weaknesses in the system of protection, representatives of the states and the League of Nations concluded that it would be necessary to strengthen the control mechanism. A minority petition procedure was, therefore, introduced as an additional tool, the organization of which was, over time, gradually modified and supplemented. ${ }^{19}$ A report presented by Tommaso Tittoni ${ }^{20}$ in 1920 and adopted by the Council of the League of Nations in October 1920 is a milestone in this respect. The Tittoni report elaborated on the provisions of the minority treaties, according to which each member of the Council had the right to bring to the Council's attention any infraction, or any danger of infraction, of a treaty provision. The report concluded that these provisions did not exclude members of national minorities or their organizations, as well as states that were not represented in the Council, from at least informally addressing the Council with regard to an alleged violation of the minority treaties. However, Tittoni acknowledged that such action by members of national minorities could not lead to the formal opening of Council deliberations and that it could only take the form of a legally nonbinding petition. Thus, the Council was not obliged to deal with such a petition.

\footnotetext{
${ }^{16}$ This fundamental problem is also well documented for the period after the Second World War. Although the instrument of interstate complaint has been introduced in a number of international human rights conventions, it has never been used at the UN level. On the regional level, there have been a few inter-state complaints brought before the European Court of Human Rights.

${ }^{17}$ These complaints were successful from a legal perspective, but in political terms they turned out to be counterproductive. See Hilpold (2006) 172.

${ }^{18}$ According to William Kurt Barth, it was in response to threats to sovereignty posed by the minority treaties that the League's system consciously deprived minorities of locus standi. Barth (2008) 57-60.

${ }^{19}$ For more details, see Pritchard (2001) 85-89.

${ }^{20}$ In 1919 Tommaso Tittoni, as the Italian Foreign Minister, led the Italian delegation at the Paris Peace Conference. According to Christoph Gütermann, the report was drafted by Eric Colban, the Head of the Minority Section at the League of Nations. Gütermann (1979) 39.
} 
Based on a Council decision of 25 October 1920, the mechanism of three-member committees on minority issues was established. The minority committees consisting of the President of the Council and two other Council members were set up in order to examine the merits of minority petitions and in order to decide whether the petitions should be submitted to the Council. The Secretary General of the League of Nations was given the mandate to review the formal receivability of petitions. According to a Council decision of 5 September 1923, the Secretary-General had to ascertain whether the petition concerned a particular minority right provided by a minority treaty, whether it was aimed at severing the political ties between the national minority and the territorial state, whether it was anonymous and whether the alleged violations had already been the subject of other recently presented petitions. With a view to similar procedures under the current international protection of human rights, it is noteworthy that in the system of the League of Nations the petitioners did not need to prove the exhaustion of all available domestic remedies in the matter. ${ }^{21}$ The territorial state, against which the minority petition was directed, was expected to submit its opinion within two months. Both the petition and the state's opinion were subsequently passed on to all members of the Council. ${ }^{22}$

Following the introduction of the new petition mechanism, the status of the complainants remained rather unclear. The problem was that the authors of the petition were not informed about the outcome of the review and relevant measures adopted by the Council. In those rare cases in which the Council secretariat provided information to the complainants, it was done in an informal and oral manner. ${ }^{23}$ It was only in 1929 that the Council of the League of Nations established the right of the complainants to be provided information on the receivability of their submissions. The same Council resolution of 13 June 1929 also laid down the duty of the Secretary-General of the League of Nations to inform all members of the Council once per year of all the communications that had been received by the three-member committees and to inform the public about the number of receivable and unreceivable petitions. However, the findings of the minority committees could be made public only with the consent of the State against which the investigation was conducted. $^{24}$

In the period between 1920, when the petitions procedure was introduced, and 1929, when the procedure was reformed, a total of 149 receivable and 306 unreceivable petitions was recorded. ${ }^{25}$ Between 1929 and 1939, minorities filed 521 petitions, of which 225 were considered unreceivable. ${ }^{26}$ Compared to similar complaint mechanisms under the current system of international human rights protection, the proportion of receivable complaints was very high. This is apparently due to the fact that a substantial number of the complaints which are filed to the UN human rights bodies and the European Court of Human Rights do not meet the domestic

\footnotetext{
${ }^{21}$ Hilpold (2013).

${ }^{22}$ Until 1923 the information about the minority cases was made accessible to all members of the League of Nations. Thereafter, the material was passed to Council members only.

${ }^{23}$ Scheuermann (2000) 36.

${ }^{24}$ Gütermann (1979) 84-117.

${ }^{25}$ Scheuermann (2000) 410-12.

${ }^{26}$ Gardiner Jones (1949) 614.
} 
remedies rule, ${ }^{27}$ whereas the exhaustion of domestic remedies was not examined by the League of Nations bodies.

Only very few petitions which had been investigated by the minority committees, were subsequently referred to the Council. It should be added that although the minority treaties themselves did not provide explicitly for the referral of petitions to the Council, this approach was sometimes used. The minority committees, however, in practice tended to rely on diplomatic and confidential negotiations with the territorial state, rather than on the legal solution of the problem before the Council.

We have to consider that after a complex drafting process, during which different legalist concepts for the League of Nations had been presented, it was especially British and USAmerican leaders who finally pushed through a clearly anti-formalist approach. According to Stephen Wertheim, during the Paris Peace Conference of 1919 legalism was demoted. ${ }^{28}$ Against this background, the League's concept of national minority protection, though not excluding legal tools and judicial settlement, clearly privileged political and diplomatic mechanisms of dispute settlement.

Of the approximately 900 petitions filed between 1920 and 1939, approximately 500 were declared receivable and referred to the minority committees. However, only 16 cases were forwarded to the Council. ${ }^{29}$ As the adoption of legally binding measures in the Council required unanimity, this tool was not considered to be a realistic option in politically tense situations. The major impact of a discussion at the Council level was moral pressure on the territorial state concerned.

In his groundbreaking study of 1979, Christoph Gütermann drew a distinction between formal and informal proceedings before the minority committees (procedure écrite and procedure non écrite).$^{30}$ In practice, the petitions procedure sometimes significantly deviated from the rules. This was true, for example, of the transmission of sensitive information to individual petitioners. Although formal proceedings were based on the principle of strict confidentiality, there were cases in which representatives of member states intensively communicated with the petitioners about the preliminary results of the proceedings. This is why in 1924 the Hungarian representative of the League of Nations, Zoltan Baranyai, explicitly warned his government of diplomatic difficulties if the petitioners disclosed the source of their information to the institutions of the League of Nations. ${ }^{31}$

It is evident that, in this context, the co-operation of a kin-state with its related minority abroad played an important role. According to Davide Zaffi, kin-states assisted the petitioners in the correct, formal drafting of their petitions. Sometimes kin-states also provided logistical assistance, as for example, when petitions were handed over to Geneva. In some cases, the kinstate coordinated the content of various individual petitions. ${ }^{32}$ Besides this, there were also cases

\footnotetext{
${ }^{27}$ According to Kevin Boyle, 90\% of all complaints to the European Court of Human Rights are rejected as inadmissible, in most cases due to the non-exhaustion of local remedies. See Boyle (2009) 165-74.

${ }^{28}$ Wertheim (2012) 210-32.

${ }^{29}$ Zaffi (1997) 197-220; Hilpold (2006) 195.

${ }^{30}$ Gütermann (1979).

${ }^{31}$ Zaffi (1997) 207-208.

${ }^{32}$ Zaffi (1997) 208.
} 
in which the representatives of the League of Nations themselves informally negotiated with petitioners, sometimes on the initiative of the relevant minority committee.

Beyond the role of the Council of the League of Nations and the impact of the petition procedure, we should not forget to mention the relevant case law of the Permanent Court of International Justice. In academic literature, there is a consensus that the potential of the Permanent Court was little used. ${ }^{33}$ For the entire duration of the system of the League of Nations, the Permanent Court issued only one judgment on the basis of a state action. ${ }^{34}$ Two other lawsuits against Poland were withdrawn by Nazi Germany. On a total of five occasions, the Council of the League of Nations requested that the Permanent Court provide a (legally nonbinding) advisory opinion. In this context, too, issues relating to the situation of the German minority in Poland prevailed ( 3 requests). The other two cases concerned the status of the Polish minority in Gdansk and the situation of Greek minority schools in Albania. Although the number of judgments and opinions delivered by the Permanent Court is not very high, case law contributed significantly to the further development of the international protection of national minorities. So, for example, the Permanent Court of International Justice dealt with the legal concept of a national minority and the principle of non-discrimination on grounds of minority group membership. ${ }^{35}$

\section{INTERNATIONAL HUMAN RIGHTS PROTECTION AS A PARADIGM SHIFT?}

Whereas the system of the League of Nations was built upon the protection of national minorities and did not include any legal and political standards for the protection of general human rights, after 1945 the United Nations intended to establish a human rights system addressed to all individuals 'without distinction as to race, sex, language, or religion'. ${ }^{36}$ Human rights protection which, from a traditional legal perspective, had been conceived as an internal affair of sovereign states was now understood as a new element or even a revolutionary change in international law.

The relation between the new field of general human rights protection and traditional minority protection was not completely clear at the beginning. Despite some drafts that aimed at including minority protection in the Universal Declaration of Human Rights, the General Assembly did not adopt an explicit minority protection clause within the frame of the Declaration. In Resolution 217 C (III) of 10 December 1948, entitled 'Fate of Minorities', the General Assembly stated that the United Nations should not remain indifferent to the fate of minorities. However, as it would have been difficult to adopt a uniform solution to the minority question, the General Assembly decided not to mention the problem in the Universal Declaration of Human Rights. ${ }^{37}$ The international community found that members of national minorities were to be protected by the non-discrimination clause provided for in the Declaration.

\footnotetext{
${ }^{33}$ Pritchard (2001) 92-96.

${ }^{34}$ Rights of Minorities in Upper Silesia, Judgment, 1928, PCIJ Series A No 15. The case concerned the conditions for admission to minority schools.

${ }^{35}$ Hilpold (2006) 178.

${ }^{36}$ See Article 1 para. 3 of the UN-Charter.

${ }^{37}$ Capotorti (1991) 26-27.
} 
In 1950 the UN Secretary-General, at the request of the Economic and Social Council, presented a study on the validity of undertakings concerning minorities ${ }^{38}$ in which he focused on the question of whether the minority treaties and minority declarations of the League of Nations' system should be regarded as being still in force. Although the Secretary-General found that the dissolution of the League did not automatically result in an extinction of the relevant obligations he maintained that the validity of the treaties and declarations had to be considered in the light of fundamental changes of circumstances. The Secretary-General pointed at four important factors of change, which were, first, the dissolution of the League of Nations, second, the operation of the minorities protection regime between the two wars which according to the Secretary-General had not produced the expected results, third, the considerable changes in the position of the States bound by the obligations concerning the protection of minorities and, last but not least, the recognition of human rights and of the principle of non-discrimination by the United Nations Charter.

With regard to the ambivalent relation between human rights and minority rights, the Secretary-General's study admitted that 'respect for human rights and non-discrimination on the one hand, and the protection of minorities on the other, are concepts which do not entirely coincide'. According to the study, the protection of minorities is a broader concept than human rights protection as it includes special privileges, e.g. in the fields of linguistic rights and education. However, the Secretary-General also found that respect for the rights and fundamental freedoms of man and non-discrimination are aimed at protecting minorities 'against the persecutions, petty restrictions and discrimination to which they are exposed'.

Although human rights protection and minority protection thus have some common goals, there are nevertheless two major differences. Whereas minority protection under the League of Nations applied only to a few states (almost exclusively in Eastern Europe), respect for human rights is built upon the principle of universal application. Unlike minority protection, which only applies to some sections of the population, respect for human rights applies to all individuals. Therefore, the Secretary-General concluded that the old minority protection system 'has to a large extent been supplanted by another', i.e. the system of international human rights protection. These arguments indicate a shift in paradigm within the concept of international law. International law is no longer to be understood as a system addressed exclusively to states and collective entities, but includes individuals and their inherent rights, as well. Nevertheless, some basic elements of the League of Nations' system have been included in the new legal field of human rights protection.

In 1966 one of the major universal human rights treaties, the International Covenant on Civil and Political Rights (ICCPR), was adopted. In its preamble, the ICCPR makes explicit reference to the inherent dignity and the equal and inalienable rights of all members of the human family and to rights deriving from the inherent dignity of the human person. The majority of ICCPR provisions contain 'everyone's rights'. However, as Article 27 of the ICCPR codifies cultural, religious and linguistic rights in favor of persons belonging to ethnic, religious or linguistic minorities, it becomes clear that human rights and minority rights form a unity or, in other words, minority rights are a part of human rights.

${ }^{38}$ UN Doc. E/CN.4/367 of 7 April 1950. 
This assumption has been confirmed even more explicitly on the regional level. In 1995, the Council of Europe opened for signature the Framework Convention for the Protection of National Minorities (FCNM). Article 1 of the FCNM stipulates that the protection of national minorities and of the rights and freedoms of persons belonging to those minorities forms an integral part of the international protection of human rights. Therefore, just like the minority treaties of the interwar period, the FCNM contains a number of human rights provisions such as freedom of assembly, freedom of association, freedom of expression, and freedom of thought, conscience and religion (Articles 7 and 8).

From an overall perspective, we may conclude that the system of international human rights law developed after World War II has not completely replaced the protection of minorities. In fact, the relevant treaties and international practice rather seek to synthesize both areas, as is particularly evident in current anti-discrimination law. In this sense, the announced paradigm shift did not take place. As we will show below, the jurisprudence of the Permanent Court of International Justice may still serve as an important source of inspiration, and guarantees a significant degree of continuity within the system of international minority protection operating before and after World War II.

\section{THE MATERIAL STANDARD OF MINORITY PROTECTION}

The material standard of protection provided by the minority treaties and minority declarations has to be understood in the light of leading cases of the Permanent Court of International Justice. The introduction of judicial supervision was indeed considered one of the important innovations in the League's system for the protection of minorities. ${ }^{39}$ Some arguments applied by the Permanent Court of International Justice are still relevant from the perspective of current minority protection.

In this respect we may consider the problem of defining the term 'minority', which has not yet been clarified by any legally binding document of international law. As there was no generally agreed definition introduced in the minority treaties after World War I, experts anxiously awaited the Court's decision in the Greco-Bulgarian Communities case. ${ }^{40}$ In this case related to the liquidation of the property of Greco-Bulgarian communities - the Court was asked to give a definition of the term 'communities'. The Permanent Court of Justice concluded that a 'community' is 'a group of persons living in a given country or locality, having a race, religion, language and traditions of their own and united by this identity of race, religion, language and traditions in a sentiment of solidarity, with a view to preserving their traditions, maintaining their form of worship, ensuring the instruction and upbringing of their children in accordance with the spirit and traditions of their race and rendering mutual assistance to each other'.

The Court added that the existence of a group within the meaning of this definition is a matter of fact and not a question of law. This means that minority status does not depend on the recognition of the minority by a national legal act. Therefore, the academic literature has emphasized that such a concept of minority is an 'an essentially non-juridical exercise' and the

\footnotetext{
${ }^{39}$ Capotorti (1991) 24.

${ }^{40}$ Interpretation of the Convention Between Greece and Bulgaria Respecting Reciprocal Emigration (Greco-Bulgarian Communities), PCIJ, Advisory Opinion, (1930), Series B No 17.
} 
approach of the Court has been considered to be 'sociological'. The distinction between empirical facts serving as a proof of the existence of a minority and respective national legal provisions has been understood as the cornerstone of the internationalization of minority protection, as facts are not dependent on national law. ${ }^{41}$

Documents adopted after 1945 show that the concept of minority based upon both objective criteria (race, religion, language and traditions) and subjective criteria (sentiment of solidarity and mutual assistance) which has been developed by the Permanent Court of International Justice is still relevant and very influential. In 1971 Francesco Capotorti was appointed Special Rapporteur of the Sub-Commission on the Prevention of Discrimination and Protection of Minorities and endowed with the mandate to analyze the concept of minority and offer an acceptable definition. Such a definition was meant to serve the purpose of the application of Article 27 ICCPR. In his famous study of 1979, Capotorti offered a definition which came very close to the concept of minority formulated by the Permanent Court of International Justice. Moreover, Capotorti combined objective and subjective criteria. Beyond ethnic, religious and linguistic characteristics Capotorti considered numerical inferiority and the citizenship requirement as objective conditions for the existence of a minority. ${ }^{42}$

A more open and progressive concept of minority has been formulated by the UN Human Rights Committee. In its General Comment No. 23 regarding the interpretation of Article 27 of the ICCPR, ${ }^{43}$ the UN-Human Rights Committee emphasized that minority rights shall not depend on citizenship. The Committee further stated that immigrants and even visitors with a relatively short residence may constitute a national or religious minority and invoke their minority rights under Article 27 of the Covenant.

If we look into state practice related to the implementation of the FCNM we see that some States Parties still rely on a rather conservative definition inspired by the Permanent Court of International Justice. Given the fact that no definition of the term national minority has been incorporated into the FCNM, numerous States Parties (a total of 18) have addressed this issue through unilateral declarations. According to some states, the FCNM shall apply to groups that meet the definition of a national minority under national law. Other states have sent either exhaustive or declaratory lists of recognized minorities that shall fall under the personal scope of the Framework Convention. Liechtenstein, Luxembourg and Malta declared that there were no national minorities on their territories and, therefore, they acceded to the Framework Convention only out of solidarity. ${ }^{4}$

The Swiss declaration contained in the instrument of ratification of 21 October 1998 comes very close to the definition provided by the Permanent Court of Justice and the Capotorti report. Switzerland declared that national minorities in the sense of the FCNM are groups of individuals numerically inferior to the rest of the population of the country or of a canton, whose members are Swiss nationals, have long-standing, firm and lasting ties with Switzerland and are guided by the will to safeguard together what constitutes their common identity, in particular their culture,

\footnotetext{
${ }^{41}$ Brölmann (2013) 133.

${ }^{42}$ Capotorti (1991) 96.

${ }^{43}$ General Comment No. 23: The rights of minorities (Art. 27), CCPR/C/21/Rev.1/Add.5.

${ }^{44}$ See, for example, the declaration of Lichtenstein of 18 November 1997: 'The Principality of Liechtenstein considers its ratification of the Framework Convention as an act of solidarity in the view of the objectives of the Convention.' Link 1.
} 
their traditions, their religion or their language. Also Estonia and Latvia in their unilateral declarations explicitly referred to both objective and subjective criteria.

Besides the problem of the definition of the term national minority, the Permanent Court of International Justice also repeatedly dealt with the issue of non-discrimination. In an early advisory opinion of 1923 the Court was asked to clarify the status of land contracts that farmers had concluded with the Prussian government before World War I in territories which, under the Treaty of Versailles, became part of Poland. According to Polish law, the Polish Government had the right to evict settlers of German origin who had become Polish nationals. Although Polish action was not exclusively related to German settlers, the Court found that the principle of equality had been violated. With a view to Article 8 of the Polish minority treaty, according to which Polish nationals who belong to racial, religious and linguistic minorities shall enjoy the same treatment and security 'in law and in fact' as the other Polish nationals, the Court stated that 'there must be equality in fact as well as ostensible legal equality in the sense of the absence of discrimination in the words of the law'. ${ }^{45}$

In a later case concerning the rights of the Polish minority in Danzig, the Permanent Court of International Justice was asked by the Council to provide an exact interpretation of Article 104 (5) of the Treaty of Versailles. The object of the quoted provision was to ensure that there would be no discrimination to the detriment of Polish nationals and other persons of Polish origin or speech in Danzig. According to the Court, the provision forbade discrimination related to the Polish character of these persons. The Court found that under the provision it was necessary to eliminate 'discrimination in fact as well as in law'. On the other hand, the object of the prohibition was 'to prevent any unfavorable treatment, and not to grant a special régime of privileged treatment'. Therefore, according to the Court, the non-discrimination clause had to be considered as purely negative. ${ }^{46}$

A few years later, in an advisory opinion of 1935, the Permanent Court of International Justice extended this very narrow concept of negative discrimination and elaborated on the notion of positive discrimination. ${ }^{47}$ The Court had to deal with an amendment to the Albanian constitution which provided that the instruction and education of Albanian subjects was reserved to the State and would be given in State schools only. Private schools of all categories had to be closed. Whereas members of the Greek minority in Albania and the Greek government argued that the legal measure was in violation of the principle of equality, the Albanian Government contended that the minority declaration of 1921 imposed no other obligation upon it than to grant to members of racial, religious or linguistic minorities a right equal to that possessed by the members of the Albanian majority. So, as the majority was not entitled to have private schools, the minority could not claim them either. According to the Albanian government, any interpretation which would compel the state to respect the right of the minority to have the private schools would create a privilege in favor of the minority.

\footnotetext{
${ }^{45}$ Questions Relating to Settlers of German Origin in Poland (German Settlers in Poland), PCIJ, Advisory Opinion (1923), Series B No 6.

${ }^{46}$ Treatment of Polish Nationals and Other Persons of Polish Origin or Speech in Danzig Territory, PCIJ, Advisory Opinion (1932), Series E No 8.

${ }^{47}$ Minority Schools in Albania, PCIJ, Advisory Opinion (1935), Series A/B No 64.
} 
The Court answered this argument by pointing to 'the ensuing special needs' of minorities and to two major principles established by the minority treaties and minority declarations. According to the Court, international documents, on the one hand, call for "perfect equality between nationals belonging to the minority and other nationals", and, on the other, minorities shall be granted suitable means for the preservation of their racial peculiarities, their traditions and their characteristics. If the minority were deprived of its own (educational) institutions, there would be no true equality.

Without any doubt, these concepts of equality and non-discrimination which were formulated by the Permanent Court of International Justice are still very influential. We may identify traces of the Court's approach towards positive discrimination in more recent documents referring to affirmative action and positive action. ${ }^{48}$ On the UN level, Special Rapporteur Francesco Capotorti in his above quoted Study of 1979 pointed to the need to include a more open notion of discrimination in the interpretation of Article 27 ICCPR. According to Capotorti, for instance, the right of persons belonging to a minority to preserve their culture would become entirely meaningless if states did not provide positive measures. A purely passive attitude on their part would render minority rights ineffective. ${ }^{49}$ In a report of 2000 Marc Bossuyt, also Special Rapporteur of the Sub-Commission on the Promotion and Protection of Human Rights, further elaborated on the concept and practice of affirmative action and made explicit reference to the case law of the permanent Court of International Justice. ${ }^{50}$

The Human Rights Committee, in its General Comment No. 23 regarding the interpretation of Article 27 of the ICCPR, ${ }^{51}$ was even more explicit and stated that positive measures by States Parties may be necessary to protect the identity of a minority and the rights of its members to enjoy and develop their culture and language and to practice their religion, in community with the other members of the group. As long as positive measures are aimed at correcting conditions which prevent or impair the enjoyment of the minority rights, they shall constitute a legitimate differentiation under the ICCPR, provided that they are based on reasonable and objective criteria.

The concept of positive discrimination, further, plays an important role for the interpretation of the FCNM. According to Article 4 (2) of the FCNM, 'States Parties undertake to adopt, where necessary, adequate measures in order to promote, in all areas of economic, social, political and cultural life, full and effective equality between persons belonging to a national minority and those belonging to the majority. In this respect, they shall take due account of the specific conditions of the persons belonging to national minorities'. This clause on 'adequate measures' might give rise to questions concerning the compatibility of such measures with the prohibition of discrimination. However, Article 4 (3) of the FCNM explicitly states that the measures adopted in accordance with paragraph 2 shall not be considered to be an act of discrimination. With a view to this provision, the Advisory Committee as the monitoring body under the Framework Convention has constantly encouraged the introduction of positive measures in favor of members of minorities which are particularly disadvantaged. ${ }^{52}$

\footnotetext{
${ }^{48}$ For more detail on those concepts, see McCrudden (2011), 157-80.

${ }^{49}$ Capotorti (1991) 36.

${ }^{50} \mathrm{E} / \mathrm{CN} .4 / \mathrm{Sub} .2 / 2000 / 11$.

${ }^{51}$ General Comment No. 23: The rights of minorities (Art. 27), CCPR/C/21/Rev.1/Add.5.

${ }^{52}$ For concrete examples, see De Schutter (2010) 71-116.
} 
Also within the frame of EU anti-discrimination law, we find references to the concept of positive discrimination or positive measures. According to Lisa Waddington and Mark Bell, positive action is a well-established element of EU legislation that can be found in various directives and has been confirmed by the jurisprudence of the EU Court of Justice. ${ }^{53}$ Although the standard of positive action under EU law has mostly been developed in the context of gender equality, we also find a provision on positive action included in the Council Directive 2000/43/ EC of 29 June 2000 implementing the principle of equal treatment between persons irrespective of racial or ethnic origin. Article 5 of the Directive stipulates that the principle of equal treatment shall not prevent any Member State from maintaining or adopting specific measures to prevent or compensate for disadvantages linked to racial or ethnic origin. Article 7 of the Council Directive 2000/78/EC of 27 November 2000 establishing a general framework for equal treatment in employment and occupation extends the concept of positive action in favor of new vulnerable minorities, such persons with disabilities, the elderly and members of sexual minorities.

However, it is fair to add that the Permanent Court of International Justice did not only lay the foundations for current doctrines of positive discrimination. In the above mentioned $M i$ nority Schools in Albania case, a minority of judges already anticipated future problems linked to this concept. In their dissenting opinion three judges, including the President of the Court Sir Cecil Hurst, though acknowledging that the provisions of the minority treaties call for effective and real equality instead of 'a platonic and paper equality', arrived at the conclusion that equality in law should not be disregarded and replaced by a system of different treatments for the minority and the majority so as to establish an equilibrium between them. According to the dissenting judges the authors of the minority treaties provisions rather had in mind the consolidation of the legal situation and did not intend to introduce "an elusive search after a perfect equilibrium".

\section{CONCLUSIONS}

Since the League of Nations' minority protection system was based on international obligations which were binding only on a few states, it did not introduce new general principles into the body of international law. Nevertheless, the material and procedural standards codified by minority treaties and minority declarations in the interwar period represent a milestone in the history of international relations. No other international organization has advanced the concept of minority protection as significantly as the League of Nations did. Therefore, the protection of racial, religious and linguistic minorities is widely understood as the most important legacy of the League of Nations.

In the foregoing contribution, we have pointed out the major elements of minority protection under the League's legal régime. Special focus has been devoted to the procedural tools of minority protection, i.e. on the petition procedure introduced by the Council of the League and on the impact of case law developed by the Permanent Court of International Justice. Despite broad ambitions and expectations the 'great experiment' ended in embarrassment. After 1945, the international community refused to continue the development of minority rights. Emphasis

${ }^{53}$ Waddington and Bell (2011) 1508-31. 
shifted from the protection of ethnic, religious and linguistic minorities to the general protection of human rights. The Austrian American international lawyer Josef Laurenz Kunz expressed this change of paradigm in an ironic manner when, in 1954, he wrote that at the end of the first World War, international protection of minorities was the great fashion represented by treaties, conferences and an enormous literature. 'Recently this fashion has become nearly obsolete. Today the well-dressed international lawyer wears human rights'. ${ }^{54}$

With regard to the relation between human rights law and minority protection we have, however, identified a certain degree of continuity. The dialectic process of international legal history has led to the synthetic assumption that minority protection is an integral part of human rights protection. Current international mechanisms have drawn inspiration from the League's experiences and the jurisprudence developed by the Permanent Court of International Justice. Some standard elements of modern anti-discrimination law can be traced back to the concepts of equality and non-discrimination applied in the interwar period.

Beyond concrete examples which have been analyzed in this contribution we may also draw a more general conclusion. A thorough look at the heritage of the League's system of minority protection shows that although international institutions, at present, are rather reluctant to deal with the specific situation of national minorities and consider ethnic and religious arguments quite obsolete, the renaissance of minority protection standards in the 1990s has shown that ethnicity matters and continues to play an important role in international law. To reject the heritage of the League of Nations would mean to ignore crucial experiences.

\section{REFERENCES}

Barth, W. K., On Cultural Rights: the Equality of Nations and the Minority Legal Tradition (Martinus Nijhoff 2008).

Boyle, K., 'The European experience: The European convention on human rights' (2009) 1 Victoria University of Wellington Law Review 167-76.

Brölmann, C., 'The Permanent Court of International Justice and International Rights of Groups and Individuals' in Fitzmaurice, M., Tams, C. J. and Merkouris, P. (eds), Legacies of the Permanent Court of International Justice (Martinus Nijhoff 2013) 123-43.

Capotorti, F., Study on the Rights of Persons Belonging to Ethnic, Religious and Linguistic Minorities (United Nations 1991).

Cowan, J. K., 'Who is afraid of violent language? Honour, Sovereignty, and Claims- Making in the League of Nations' (2003) 3 Anthropological Theory 271-91.

De Schutter, O., 'The Framework Convention on the Protection of National Minorities and the Law of the European Union' in Henrard, K. (ed), Double Standards Pertaining to Minority Protection (Leiden 2010) 71-116.

Fenwick, C. G., 'The “failure” of the League of Nations' (1936) 3 American Journal of International Law 506-509.

${ }^{54} \mathrm{Kunz}(1954) 282$. 
Finch, G. A., 'The Progressive Development of International Law by the League of Nations' (1947) 4 The American Journal of International Law 611-16.

Gardiner Jones, M., 'National Minorities: A Case Study in International Protection' (1949) 4 Law and Contemporary Problems 599-626.

Goodrich, L. M., 'From League of Nations to United Nations' (1947) 1 International Organization 3-21.

Gütermann, C., Das Minderheitenschutzverfahren des Völkerbundes (Duncker \& Humblot 1979).

Hilpold, P., 'Minderheitenschutz im Völkerbundsystem' in Pan, C. and Pfeil, B.S. (eds), Zur Entstehung des modernen Minderheitenschutzes in Europa (Springer 2006) 156-89.

Hilpold, P., 'The League of Nations and the Protection of Minorities - Rediscovering a Great Experiment' (2013) 1 Max Planck Yearbook of United Nations Law 87-124.

Kunz, J. L., 'The Present Status of International Law for the Protection of Minorities' (1954) 2 American Journal of International Law 282-87.

Magocsi, P. R., 'The heritage of autonomy in Carpathian Rus' and Ukraine's Transcarpathian region' (2015) 4 Nationalities Papers 577-94.

McCrudden, C., 'A Comparative Taxonomy of "Positive Action" and "Affirmative Action" Policies' in Schulze, R. (ed), Non-Discrimination in European Private Law (Mohr Siebeck 2011) 157-80.

Pedersen, S., 'Back to the League of Nations' (2007) 4 American Historical Review 1091-1117.

Pritchard, S., Der völkerrechtliche Minderheitenschutz. Historische und neuere Entwicklungen. (Duncker \& Humblot 2001).

Scheuermann, M., Minderheitenschutz contra Konfliktverhütung? Die Minderheitenpolitik des Völkerbundes in den zwanziger Jahren (Herder-Institut 2000).

Stone, J., International Guarantees of Minority Rights; Procedure of the Council of the League of Nations in Theory and Practice (Oxford University Press 1932).

Tosi, L., 'The League of Nations: An international relations perspective' (2017) 1 Uniform Law Review 14857.

Waddington, L. and Bell, M., 'Exploring the boundaries of positive action under EU law - a search for conceptual clarity' (2011) 5 Common Market Law Review 1508-31.

Weisbrod, C., 'Minorities and Diversities: The Remarkable Experiment of the League of Nations' (1992) 2 Connecticut Journal of International Law 359-406.

Wertheim, S., 'The League of Nations: A Retreat from International Law?' (2012) Journal of Global History $210-32$.

Zaffi, D., 'Die Minderheitenpetition im Rahmen der Politik des Völkerbundes' in Corsini, U. and Zaffi, D. (eds), Die Minderheiten zwischen den beiden Weltkriegen (Duncker \& Humblot 1997).

Link 1: the declaration of Lichtenstein of 18 November 1997 <http://www.coe.int/en/web/conventions/fulllist/-/conventions/treaty/157/declarations?p_auth $=\mathrm{CaLrCrcY}>$ accessed 8 February 2019. 